\title{
Islamic Renewal Project: Ḥassan Ḥanafi and Indonesian Intellectual Muslims
}

\author{
Syafieh \\ Institut Agama Islam Negeri (IAIN) Zawiyah Cot Kala \\ syafieh@iainlangsa.ac.id
}

\begin{abstract}
This article aims to examine the Islamic reform project through the reconstruction of theology and thought carried out by Ḥassan Ḥanafì and Indonesian Muslim intellectuals. Ḥassan Hanafì considered the need to reconstruct classical theology, which is regarded as too abstract in describing theological terms and does not have a strong practical basis as a value for the action. In criticizing classical theology, Ḥassan Ḥanafĩ offers two theocentric theories, namely language analysis, and social reality analysis. Conducting library research that relies on written materials and analyzed with content analysis techniques, the present study shows that Hassan Hanafîs theoanthropocentric theological ideas have intersections with the development of Islamic thought in Indonesia. This can be proven by the translation of Hassan Hanafís books and examining his thoughts in Indonesia. Apart from that, Hassan Hanafi's thoughts find relevance in Indonesia because Indonesian Muslim scholars carry out similar reform projects.
\end{abstract}

Keywords: Ḥassan Ḥanafï, Islamic reform, theological reconstruction, classical theology, Indonesian Muslim scholars

Abstrak. Artikel ini bertujuan untuk mengkaji tentang proyek
pembaharuan Islam melalui rekonstruksi teologi dan pemikiran yang
dilakukan oleh Hassan Hanafī dan para intelektual Muslim Indonesia.
Ḥassan Ḥanafī menilai perlunya mengadakan rekonstruksi terhadap
teologi klasik yang dianggap terlalu abstrak dalam mendeskripsikan
term-term teologi dan tidak memiliki basis praksis yang kuat sebagai
nilai bertindak. Dalam melakukan kritik terhadap teologi klasik, Ḥassan 
Ḥanafì menawarkan dua teori yang bersifat teosentris yaitu analisa bahasa dan analisa realitas sosial. Dengan melakukan penelitian kepustakaan yang bertumpu pada bahan-bahan tertulis dan dianalisis dengan teknik analisis isi menunjukkan bahwa ide teologi teoantroposentris Ḥassan Ḥanafì memiliki persinggungan pada perkembangan pemikiran keislaman di Indonesia. Hal ini dapat dibuktikan dengan penerjemahan buku-buku Ḥassan Ḥanafī dan pengkajian terhadap pemikirannya di Indonesia. Di samping itu pemikiran-pemikiran Ḥassan Ḥanafì menemukan relevansinya di Indonesia karena proyek pembaharuan serupa juga dijalankan oleh para cendekiawan Muslim Indonesia.

Kata Kunci: Ḥassan Ḥanafi, pembaharuan Islam, Rekonstruksi Teologi, Teologi Klasik, dan Cendekiawan Muslim Indonesia.

\section{Introduction}

$\mathrm{H}$

assan Hanafì is one of the foremost revolutionary thinkers in the Islamic world (Hanafi, 2001, 23). Hassan Hanafi's background of thought was heavily influenced by socio-political developments in Egypt (Andriansyah, 2015, 161-83) and, in general, on the condition of Muslims whose religious attitudes were too textual (Syafieh, 2020, 137). At the same time, colonialism, imperialism, zionism, and capitalism from the West had become a real threat (Shimogaki, 2012, 5). Departing from the Muslims condition, Hassan Hanafî launched a big project called al-turath wa al-tajdid (tradition and renewal). This thought project wanted the progress of Islam and the independence of the ummah and carry out a turath the revolution which was still significant as the basic formation of Muslim culture (Hanafi, 1989, 230).

Azyumardi Azra assessed that there are three main dimensions in Hassan Hanafi's idea. First, the reexamination of al-turath al-Islami (Islamic heritage or tradition). Second, the transformation and formulation of "Islamic revolutionary theology" through the process of Min al-Aqidah ila al-Thaurah (from faith to revolution). Third, a thorough and comprehensive analysis of the Western intellectual and traditional heritage from a non-Western perspective results in Ilm al-Istghrab or Occidentalism, which is an alternative to orientalism (Azra, 2003 , xvi). The realization of this thought project began by Hassan Hanafi by rebuilding the power of monotheism as a revolutionary theology to liberate the Muslim countries from the grip of the occupiers, realize justice, freedom of thoughts and opinions, unity of the people, progress, safeguarding the identity of the nation, and promoting revolution. All these efforts are reflected in the ideas of al-Yasar al-Islami (the Islamic Left) Ḥassan Ḥanafĩ which links the 
science of monotheism with the unity of the people and people's culture, prophecy with the movement of history, revolution, and the earth, humans, and history. As well as, movements and times. This thought project hopes that no one is silent and backward. There will be no oppression and coercion of civilization to become the only human civilization.

The new concept of Islamic theology offered by Hassan Hanafi aims to make classical theology a stagnant dogma and become an ethical foundation and motivation for human action. To that end, Hassan Hanafĩ tries to transform traditional theology, which is theocentric to theo-anthropocentric, from God to man, from textual to contextual, from theory to action, and from destiny to free will. Hassan Hanafì's thought was based on three reasons. First, the need for an ideology (theology) is clear in the midst of the global struggle between various world ideologies. Second, the importance of a new theology, which has theoretical reliability as a new ideology of movement in history. Third, the importance of practical theology ('amaliyah filiyah), which is manifested in a real way to change Muslims condition (Ridwan, 1998, 50).

For Hassan Hanafi, theology is not a sacred science given by God, which is sure to be accurate and must be accepted without question. Theology is a product of history, so it needs to be renewed. In the contemporary context, classical theology can no longer be a handle and a living perspective to motivate action. Hassan Hanafĩ emphasizes this in his book Min al-Aqidāh Ila al-Thawrah; Muhawalatun li I'adat Bina' 'Ilm Usūl al-Dīn (From Faith to Revolution; Efforts to Rebuild Ushuluddin's Knowledge). Ḥassan Hanafi stated that traditional theology has failed to become a functional ideology. This failure occurred because theologians did not attach theological views to pure consciousness and human action values. This has led to the emergence of a conflict between theoretical faith (al-tawhid al-nadari) and practical faith (al-suluk al-'amali) in Muslims, both individually and socially, causing the ummah to be divided and torn apart (Hanafi, 1988, 68). Hassan Hanafi's goal is to rebuild the theologian or science of ushuluddin where the faith becomes a revolutionary force by turning it into an active force to break history (Verhak and Imam, 1997, 174).

The idea launched by Ḥassan Hanafì received a severe response in Indonesia and nourished the tradition of Islamic thought, which was also developed by Indonesian Muslim scholars. There are several reasons why the idea of the Islamic Left and Hassan Hanafi's reconstructive classical theology increasingly encourages the re-actualization of Islamic thought in Indonesia. First, there is awareness of the renewal of Islamic thought in Indonesia to face the modern world marked by advances in science and technology that Nurcholis Madjid (Cak Nur) calls the technical century (Anwar, 1993, 47). Second, there is high awareness among intellectuals at Indonesian Islamic universities to fix Muslims' 
thinking so that they can compete with modern civilization. Third, Indonesian Islamic reformers' understanding of the need to reconstruct classical Islamic theology with an ethnocentric-normative orientation towards anthropocentricsocialist (Wahid, 2000, 10-13). Fourth, Hassan Hannafi's own theological reactualization project was not built by discarding classical theological concepts but instead reconstructing them to maintain their relevance (Hanafi, 2000, 12).

This article will analyze Ḥassan Ḥanafi's theo-anthropocentric theology as a form of his reform project and its relationship with the re-actualization of contemporary Islamic thought in Indonesia. This article will show that Hassan Hanafi's idea of theo-anthropocentrism theology has its place among Islamic intellectuals in Indonesia and shows similar efforts being promoted by Indonesian Muslim scholars. Thus, the reforms pursued by Hassan Hanafi further enriched the material for thinking about reform work carried out by Indonesian Muslim scholars themselves. This article will be divided into five sections. The first part contains an introduction, followed by a discussion of the biography of Hassan Hanafì and theological-anthropocentric theological thoughts, Hassan Hanafi's contact with Indonesian Islam, the renewal of Islamic thought carried out by Muslim scholars in Indonesia. Then this discussion ends with a conclusion.

\section{Brief Biography of Ḥassan Ḥanafì}

Ḥassan Hanafi was born in Cairo, Egypt, on February 13, 1935 (Faisol, 2011, 23). He was born from the Bani Suwayf family. His great-grandmother came from the Berber and Bedouin Tribe of Egypt. He started studying al-Qur'an at Syaih\} Sayyid, a scholar in Egypt, learned al-Muallimin, and finished his elementary school at Madrasah al-Silahdar (Faisol, 23-24). Ḥassan Ḥanafì continued his education at the Tsanawiyah madrasa level, namely the Stanawiyah Khali> 1 Agha madrasah. It was during his education at the Tsanawiyah madrasah that Hassan Hanafi's critical awareness began to emerge. Meanwhile, his nationalism awareness grew when he and his friends joined Ahmad Husin's Battalion.

The political dynamics in the Middle East at that time attracted Hassan Hanafì to follow its developments. The liberation of Palestine was his main interest. Hassan Hanafi's spirit of the struggle was even more flared when he saw the efforts of the heroes who died on the battlefield. Since then, his thinking horizons have begun to emerge and he sees that there is something wrong with the construction of Islamic theology that Muslims have practiced. This became the background for the birth of Hassan Hanafi's thoughts to reconstruct Islamic theology. In Hanafi's view, this earth is a new locus of monotheism, which must be maintained and utilized for the common good. Hassan Hanafi explains that this "land theology" even caught his eye long before he was in the United States 
(Hanafi, 2003,9).

While in Madrasah 'Aliyah, he became acquainted with Ikhwanul Muslimin (IM), an Islamic organization that grew up in Egypt at that time. Even Hassan Hanafì met directly with the phenomenal figure of IM (Hanafi,17-18), Hasan alBanna, when he was attending IM's briefing orientation program. Hassan Hanafi's activeness as a member of IM continued until he studied at Cairo University, Egypt. Hassan Hanafĩ always takes part in the movements recognized by the IM on his campus. On October 11, 1965, with courage and enthusiasm, he left Egypt and decided to continue his studies at the Sorbonne University at his own expense and arrived in Marseille on October 17, 1965 (Hanafi, 28). At the Sorbonne University, Hassan Hanafì studied Western philosophy, especially the thoughts of Karl Marx and Edmund Husserl to Jean Guitton, Professor of Philosophy and reformer of the Catholic tradition. As Ḥassan Ḥanafì himself admitted in his autobiography entitled "al-Usüliyyah alIslämiyyah dalam al-Dìn wa al-Thawrah fi Misr 1952-1981", Jean Guitton was very instrumental in leading him to explore the realm of philosophy West (Hanafi, 1989). Favor to Jean Guitton, Ḥassan Ḥanafì was able to build a solid foundation of his thoughts. Hassan Hanafi understands that a philosopher needs a substance from the philosophy that must be worked on, then concludes. At its peak, it understands philosophy to the purely metaphysical realm of the process. Hassan Hanafĩ exemplifies Descartes, who started his philosophy from cogito, Pascall, who started from the faith, Henri Bergson, who started from perception, memory, evolution, or inner desire. In contrast, Merleau-Ponty started his philosophy from the body and sensory knowledge (Hanafi, 1989, 235236). Every philosopher has his starting point in exploring the long and broad path of the creative process of philosophy as awareness and a practical step.

In 1966, Ḥassan Ḥanafì was able to obtain his master's degree and his doctoral degree simultaneously (Syarifuddin, 2013, 413-448). When he finished his studies in France, he was only 33 years old, still young enough to earn a doctorate at Sorbonne University. Hassan Hanafì wrote a thesis entitled "Lest Methodes d'Exegeses: Essei sur La Science des Fondament de La Comprehension IIm Ușul Figh, and his dissertation entitled "L'Exegeses de la Phenomenologie Letat Actuael de la Methode: Phenomenologie et Son Application an Phenomena Religuex", 9oo pages thick (Ja'far, 2002, 179). In 1961, the dissertation was awarded the best work in Egypt and received appreciation from Egyptian academics (Wahid, 2004, viii). From this academic achievement, Hassan Hanafi's career was brighter. Invitations as speakers at home and abroad kept coming so that his academic career took off and was increasingly recognized by the public. On his return from France, Hassan Hanafi taught at Cairo University as a lecturer in 1967- $1980 \mathrm{AD}$. In 1980, he was confirmed as a professor of 
philosophy at Cairo University. Hassan Ḥanafì has also been involved in various scientific and social organizations in Egypt, Africa, and Arabia (Andriansyah, 164-165). Ḥassan Hanafĩ later became a visiting lecturer in France (1969), Belgium (1970), Temple University Philadelphia USA (1971-1975), Kuwait University (1979), and Fez University Morocco (1982-1984). He was also appointed visiting professor at the University of Tokyo (1984-1985), in the United Arab Emirates (1985), and served as program advisor at the United Nations University in Japan (1985-1987). Apart from being a guest lecturer, Hassan Hanafi attended international seminars in various countries, such as the Netherlands, Sweden, Portugal, Spain, India, Sudan, Saudi Arabia, Malaysia, Singapore, the Philippines, Senegal, and Indonesia, which took place between 1980-1987. During these visits, he met many well-known thinkers who then provided a broader perspective on human and Muslim issues. He can also observe firsthand the contradictions and suffering of the weak that are happening in various worlds. Hassan Ḥanafî had witnessed revolutionary religion in the United States, and in Latin America, he witnessed and felt very well the development of the liberation theology movement. New understandings from all of his trips to various countries opened Ḥassan Ḥanafi's insights and thoughts that Islam must be returned to its essence, namely a religion of liberation that cares about human issues.

\section{Critique of Classical Theology and Theology-Anthropocentric Offerings}

Hassan Hanafì criticizes the classical theological thinking model on four things. First, the concept of divinity in classical theology is too abstract because theologians cannot relate it to historical, human, and Muslim realities (Hanafi, 1991, 84-86). Second, classical theology cannot lead to a comprehensive belief and knowledge of God. Hassan Hanafì believes that methodologically, classical theology cannot lead to comprehensive knowledge and belief about God and other spiritual beings (Soleh, 2013, 63). Third, classical Islamic theology was uprooted from the historical context of its birth. According to Hassan Hanafi, the birth of classical Islamic theology should not be pure thoughts presented in the emptiness of history, but rather the result of the political-socio-economic discourse at the theology time. Regarding this view, Ḥassan Hanafì equates Islamic theology with anthropology, which positions humans as both the subject and the object of discourse. Fourth, classical Islamic theology lacks practical value for the life of Muslims. In Hanafi's view, classical Islamic theology lacks a truly living understanding that can provide spiritual-transcendental motivations for human life activities (Ridwan, 47).

Departing from his criticism, Hassan Hanafĩ proposed two theories to solve the shortcomings of classical theology, which is theocentric. First, through 
language analysis. In the majority of Muslims, the terms in classical theology are inherited and have become doctrines. But for Hassan Hanafï, these terms also contain empiric-rational methods and scientific characteristics. Second, social reality analysis. The historical-sociological background of the emergence of theology in the past, an analysis of social reality, is needed to determine its impact on the life of the community or its adherents. Likewise, the analysis of social reality can be used to determine the direction and orientation of contemporary theology (Soleh, 56 ).

Meanwhile, in designing the reconstruction of Islamic theology, Hassan Hanafĩ was based on three methodologies: First, the dialectical method. Hassan Hanafi utilizes this method in analyzing the historical aspects of Islamic theology as well as formulating the reconstruction of its theology. In practical terms, dialectics is a method of thinking based on the assumption that the historical process occurs through dialectical contradictions. That is, the thesis will give rise to antithesis, and in the end, antithesis will give rise to synthesis as the final form of dialectical construction. Hassan Hanafi uses the dialectical method in analyzing the historical roots of the growth of Islamic theological thought, and he finds that classical theology in discussing divinity does not relate to the reality and history of humanity that grew at that time. Departing from this thesis, Hassan Hanafi then looks for the antithesis in the modern tradition where humans are placed as the central point of civilization. Therefore, Ḥassan Ḥanafī places man, nature, reason, society, man, and history at the center of Islamic theology reconstruction.

The results of the thesis and antithesis, Hassan Hanafi, concluded in the form of a reconstructed synthesis of Islamic theology, which we can find in his thought construction, namely theo-anthropocentric theology. Anthropocentric theology is a synthesis of Hanafi's efforts to reconcile the thesis (classical theology) and antithesis (modern tradition). Although Hanafi criticizes classical theology, he does not throw it all away. Hanafi still takes important values that exist in classical theology. Likewise, with modern traditional construction, Hanafi does not adopt all the values of Western traditions. Hassan Hanafi considers that there are weaknesses in Western thought, especially in the absence of a strong theological-spiritual basis, which results in the emergence of massive secularization in Westerners' lives.

Second, the phenomenological method. Hassan Ḥanafĩ uses phenomenology to look for practical values from Islamic theology related to his time's realities. Ḥassan Ḥanafĩ uses Husserl's phenomenology as a theoretical basis to understand and describe social realities, political economy, Islamic realities, and the reality of Western challenges by focusing on theology's reconstruction. Hassan Hanafĩ uses phenomenology in its entirety to understand the reality of 
Muslims both in the political, economic, educational, social, and cultural contexts. In his observations, Hassan Hanafi uses three reductions in phenomenology, namely phenomenological, eidetic, and transcendental decrease to be able to see the nature and produce an objective understanding of the religious phenomenon of Muslims (Hanafi, 2003, 9o). From the results of his study of Muslims' religious reality, Hassan Hanafí concluded that the constructive and progressive theological-ideological foundations had been lost from the religious reality of Muslims so that the existing theology did not have a comprehensive structure as a basis for practical Muslim action. According to Hassan Hanafi, classical theology cannot be used as a foundation and motivation for Muslims in facing their present and future history because classical theology is only busy with discourses on God, not focusing on practical teachings.

Through phenomenological reading, Hassan Hanafì offers a theoanthropocentric theology concept. This theology is built from the foundation of revolutionary thought, namely the reconstruction of classical theology based on the effort to offer human ideas. Anthropocentric theology leads to a realisticprogressive view of Islam and life following space and time's insistence in their respective contexts. For Hassan Hanafï, this theo-anthropocentric theology is dynamic because it will always follow time and space and the spirit of his era that wants to enter the scriptural text (Hanafi, 2000, 9). Third, the hermeneutic method. Hassan Hanafì uses the hermeneutic method to critically constructively read the word of Allah so that the true values in the Qur'an can be understood, especially those related to the conception of theology (Hanafi, 1981, 84-86). Hassan Hanafĩ used this method as a first step in exposing the weaknesses of classical theology, which was significantly reduced by the interests of the theologians of his time, especially at the terminology level (Soleh, 58 ).

Hassan Hanafi views that hermeneutics is a science that shows the relationship between humans and their objects, starting from empirical reality. It becomes a transformation guide for practical action. Ḥassan Ḥanafì uses the hermeneutic method as a model of interpretation in understanding al-Qur'an texts related to the conception of Islamic theology. With the foundation of hermeneutics, Hassan Hanafì made critical steps in understanding the text as well as operationalizing the reconstruction from theocentric to theoanthropocentric theology. In operating hermeneutics of scripture texts, Hassan Hanafi emphasizes three essential processes. First, someone must have "historical awareness", namely the awareness that the text is truly original and has historical certainty. Second, one must have an "eidetic state", namely awareness of the importance of rationalization in interpreting the text's meaning. Third, a person must have "practical awareness", namely human 
awareness that Allah's revelation can be a reference in human action (Hanafi, 22-35). These three methods are Hassan Hanafi's solutions to his criticism of the classical Islamic thought model. Dialectics is the answer to the weaknesses of classical theology's historical aspects; meanwhile, phenomenology and hermeneutics are used by Hanafi to overcome the weaknesses of classical theology from the aspects of terminology and praxis.

\section{The Ḥassan Ḥanafî Renewal Project and It's Intersection with Islamic} Thoughts in Indonesia

The wave of reform in the Islamic world carries the same desire in Indonesia. Indonesian Muslim scholars are attemtpting to reform various aspects of Islam, including in the field of ahl al-sunnah wa al jama'ah theology or Asy'ariah theology, which is embraced by most Indonesians (Farida, 2014, 41-56). Hassan Hanafi's idea about the need to reconstruct Islamic theology then shows its relevance in the religious reality of Indonesian Muslims who need reform to be able to face modernity. Intellectuals in Indonesia also welcomed Hassan Hanafi's ideas. Since 1993, Hassan Hanafi's thoughts on the al-Yasar al-Islami have been seriously studied by intellectuals. The discussionstook place at Paramadina. The results of the discussion were published in an edition of the journal Islamika in July 1993. In September 1993, Lembaga Kajian Islam danSosial (Institute for Islamic and Social Studies) Yogyakarta also published a book by Kazuo Shimogaki which provided a monograph or introduction to understanding the phenomenon of the Islamic Left, with the original title Between Modernity and Postmodernity The Islamic Left and Dr. Hassan Hanafi's Thought: A Critical Reading, which was later translated into Indonesian, which was preceded by a foreword by Abdurrahman Wahid (Gus Dur). One of the subjects in the book is the concept of tawhid, which no longer only talks about God and mentality but includes humans and their history. The purpose of the reconstruction of the concept of tauhid is to function in the thinking of Muslims, in social institutions, politics, and Islamic civilization as a whole.

At its peak, in 2000 to be precise, on November 5-8, IAIN Walisongo Semarang held an international seminar on the theme "Islam and Humanism" by inviting Hassan Hanafi and other thinkers from within and outside the country. After Hassan Hanafi's arrival, books and discussions about his thoughts in Indonesia became even more massive. The enthusiasm of Indonesian intellectuals in studying and discussing Hassan Hanafi's thoughts was carried out by the reformers who were already popular and young intellectuals who had high enthusiasm for reforming Islam in Indonesia. Likewise, the spirit of studying Hassan Hanafís thoughts has penetrated all Islamic universities in 
Indonesia. The illustration above shows that the theology-anthropocentric idea is very relevant and finds its ground in Indonesia. This happens because of several things: first, there is an awareness of renewal that has emerged in the landscape of Islamic thought in Indonesia. In facing the modern world marked by advances in science and technology, Indonesian Islamic reformers encouraged Islamic thought's re-actualization. For example, this has been voiced by Nurcholish Madjid when he gave a paper for a closed seminar in 1970, with the title "Keharusan Pembaharuan Pemikiran Islam dan Masalah Integrasi Umat" (The necessity of renewing Islamic thought and the issue of integration of the ummah) (Barton, 9-10.). Second, this awareness is increasingly spreading according to the reform efforts made through Islamic universities by intellectuals. Islamic tertiary institutions, as Islamic educational institutions, provide an opportunity for the idea of reform to develop systems and develop, firmly in its theoretical formulations and practical in its application. The modern civilization that blows from the West is an important challenge for reforming Islamic thought. Third, there is awareness from Indonesian Islamic reformers about the need to reconstruct classical Islamic theology with a theocentric-normative orientation towards anthropocentric-socialist. In this case, several Indonesian Islamic reformers emerged who reconstructed Islamic theology such as Harun Nasution who initiated rational Islam, Gus Dur offered the theology of Transcendental Humanism, Moeslim Abdurrahman with Transformative Islam, Kuntowijoyo with Transformative Social Sciences, and Masdar Farid Mas'udi with the Religion of Justice (Wahid, 2000,10-13). Fourth, Hassan Hanafî in re-actualizing classical theology did not abandon his concepts at all but instead acted as a staunch defender of Classical Islamic theology.

However, although the theo-anthropocentric reform project formulated by Hassan Hanafì has made a move on Islamic thinking in Indonesia, the idea is not without problems. The researcher sees that the impact of Hassan Hanafi's theo-anthropocentric theological thinking in Indonesia is insignificant or even has no effect on the development of Indonesia's Muslim community. In this case, the researchers looked at several reasons why the concept had a less significant impact. First, Hassan Hanafi's theo-anthropocentric theological concepts are too elitist. This understanding is difficult to understand and rooted in the Muslim masses or only a handful of intellectuals understand. Because of this, Hassan Hanafi's revolutionary thinking seems utopian because it cannot touch the public at large. Second, Indonesian Muslims are still comfortable with the concept of classical Asy'ariyah theology. As explained above, the majority of Indonesian Muslims are Sunnis. According to the Indonesian Muslim community, Asy'ariyah theology is very comprehensive. According to them, the monotheism that Indonesian Muslims have so far believed is not a skyrocketing 
abstract teaching as criticized by Hassan Hanafï, but is directly related to individual and social life issues. They also hold the view that today's Islamic theology is theocentric and anthropocentric because it covers all aspects of human life. Third, most Indonesian Muslims are still allergic to philosophy. Therefore, Hassan Hanafi's theo-anthropocentric theology is difficult to accept because it is built on a philosophical basis. Hassan Hanafí uses dialectics to answer the weaknesses of the historical aspects of classical theology, phenomenology, and hermeneutics to answer the weaknesses of the terminology and praxis aspects of classical theology. Therefore, Hassan Hanafís anthropocentric theology does not get a place in Indonesian Muslims' hearts who are still quite closed to accepting Western philosophy, especially those used by Hassan Hanafì. However, the efforts of Hassan Hanafì in reconstructing classical theology from theocentric to theo-anthropocentic should be appreciated. Apart from being original, Hassan Hanafís views also have the revolutionary power to change Muslims condition.

\section{Renewal of Islamic Thoughts in Indonesia}

The reconstruction of theo-anthropocentric theology carried out by Hassan Hanafi is quite relevant in Indonesia because thinkers and reformers in Indonesia have also developed the reconstruction of Islamic theology as done by Hassan Hanafi. Indonesian Scholars have built the ground for the renewal of Islamic thought, and each has a relatively large role and urgency. Some Indonesian Islamic reformers such as Harun Nasution, Abdurrahman Wahid (Gus Dur), Moeslim Abdurrahman, Masdar F. Mas'udi, and Kuntowijoyo can be said to have the same ideas as Ḥassan Ḥanafi's theological reconstruction idea, although with different terms. Harun Nasution is one of the Indonesian Muslim thinkers who opened up works of Islamic reform. Harun Nasution launched a change in the traditionalist Islamic paradigm towards a rationalist Islamic paradigm. In this effort, Harun Nasution offers the principles of rationality that have been tested in the history of classical century Islamic thought. The jargon used by Harun Nasution is "Rational Islam," whose primary point of renewal is the need to review Islamic teachings by using rational reasoning so that Muslims can answer and respond to changes and catch up.

There are three basic principles that become Harun Nasution's thinking model. First, the idea of progress is the opposite of the old-fashioned or static view of Islamic thought. One of Harun Nasution's metaphysical assumptions is change (being as process-being as progress). Therefore, the basic principles of thought must lead to progress because the dynamics of knowledge always develop in accordance with the changing times. Second, the coexistence between the absolute-textual $\left(\right.$ qat $\left.^{\prime} i\right)$ and relative-contextual (zanni) areas as the 
development of science in Islam. The categories qat $i$ (absolute) and zanni (relative) originate from ushul figh. Harun Nasution quoted and then added his content with philosophical elements. However, Harun Nasution did not always use this term. According to Dawam Raharjo, at the beginning of his intellectual career, the frequency with which Harun Nasution used this term began to use the term absolute and relative rarely (Nurisman, 2005, 172). Third, the resistance of entities in binary opposition between rational and traditional. According to Harun Nasution, if you want to change the future, you will reformat thinking. The rational thinking method concerns how epistemology works. Harun meant a scientific rationale, not rational in the sense of "reasonable". Rationalism, rationalism, and rationalists do not just believe in ratio but must prioritize the main sources of Islamic teachings, namely the revelation of the al-Qur'an and hadith. Traditional thinking is an Indonesian thinking model constructed by prehistoric Indonesian dynamism thinking. According to Harun Hasution, conventional thinking is thought in which reason has a low position and vice versa in rational culture (Nurisman, 2005, 224).

According to Harun Nasution, people or parties who are pro to freedom of thought are called rational, while those who are pro to textual both revelation and hadith are called traditional. Harun Nasution further emphasized that supporting rationality does not include free thinkers, such as Ibn al-Rawandi and al-Razi. In Islam, the use of reason is not given absolute freedom but is also not tightly bound to inhibit thinking. To build a rationality framework, Harun Nasution explained two theories regarding the nature of knowledge. First, realism, which is an understanding that believes that experience is the true picture of what is in the real world; second, idealism, this theory criticizes the first theory. This theory argues that knowledge is a subjective mental and psychological process, so knowledge is a subjective description of reality. Meanwhile, according to Harun Nasution, there are two theories about how to know, namely: first, empirical, namely knowledge obtained by the five senses; second, rationalism, namely knowledge acquired by reason. The five senses are also needed, but it is the reason that connects data so that it becomes knowledge (Nurisman, 2005, 232).

Apart from Harun Nasution, Abdurrahman Wahid (Gus Dur), a prominent figure in the community organization Nahdlatul Ulama (NU), also criticized theology for seeing the reality of the diversity of Indonesian society which was too formalistic-intellectual. In his theological ideas, Abdurrahman Wahid offers the concept of Transcendental Humanism Theology. In contrast to classical theologians, Abdurrahman Wahid divides theology into two interrelated perspectives, namely the divine perspective and the human perspective. The divine view will not be perfect without a human perspective, and vice versa. For 
Abdurrahman Wahid, theology's task is not to defend God because God for Abdurrhaman Wahid does not need to be defended. God has grown up on his own. Man's defense for God does not make Him any bigger. What humans need to support is fellow humans. Defending humans is the same as defending God. Conversely, defending God will not necessarily result in the defense of humans. It is not confident that defending God will get the blessing of God as supporting Him through violent ways such as someone who commits, in the name of God, suicide bombs, or kills people who are considered infidels and apostates.

Abdurrahman Wahid's Transcendental Humanistic theology building departed from QS. Al-Baqarah [2]: 177. According to Abdurrahman Wahid, this verse contains two sides of human motion pattern in theology, namely vertical motion, and horizontal motion. The vertical motion is transcendental, and the horizontal motion is humanistic immanent. The vertical movement is to believe in Allah, the next day, angels, books, prophets, establish prayers, and be patient in hardship, suffering, and in war. While the horizontal movement gives the property that they love to their relatives, orphans, poor people, travelers (who need help), and people begging, freeing my slave, paying zakat, and keeping promises. Abdurrahman Wahid realized that this immanent humanistic aspect had not yet been formulated and agreed upon as a matter of theology. This aspect is still considered a political problem. According to him, this problem is classified in the "chapter of jihad" which is only a farā kifayah law. Without emphasizing the immanent humanistic aspects, a person can be a person who is very faithful to the transcendent aspect but has an asocial attitude. On the other hand, a person has high social sensitivity but does not have faith in the Most Transcendent. This is a non-unified (tawhid) and contradictory action.

According to Abdurahman Wahid, one-way faith that only focuses on the transcendent aspect will form selfish faith. Meanwhile, immanent social works without transcendent faith will place a person in a post-world perspective void. Abdurrahman Wahid, therefore, rejects the capitalist system even though it is in a renewed performance. Without the transcendent aspect, nothing can guarantee that social work will not turn into capitalistic work. On the other hand, selfish faith will be counterproductive to human visions. Abdurrahman Wahid's transcendental humanist theology is aimed not only at Muslims but also at humankind in general. Abdurrahman Wahid based this view on Q.S. alHujurat, 49: 13 (Wahid, 2000, 207-208). That all human beings before Allah SWT have the same rank except their takwa. This understanding is not monopolistic only for Muslims. To strengthen this argument, Abdurrahman Wahid quoted two verses; QS. al-Fușșilat, 41: 33 and QS. Ali 'Imran, 3: 104. In QS. al-Fușșilat, 41:33, Allah explains that righteous deeds are only for Muslims, but in the second verse of Q.S. Ali 'Imran, 3: 104 there is a general word ta'muruna bi al-ma'ruf, 
including to non-Muslims. Abdurrahman Wahid's transcendental humanist theology does not prevent Muslims from doing good to non-Muslims. This theology does not encourage its adherents to be narrow formalist and ideological, as shown by the hard-line Islamic movement that strives to present Islamic shariat.

Besides, in the 1980s, together with Romo Mangunwijaya, Abdurrahman Wahid intensely discussed about liberation of theology to fight for the rights of the state's people. During the New Order era, Abdurrahman Wahid had become a figure who received serious attention from the government. Abdurrahman Wahid's thoughts and movements always reflect criticism of the state, especially when he defends the interests of minorities, both religion and other human rights issues. Gus Dur developed an expression of the paradigm of liberation theology in Indonesia and the application of criticism as in critical social science. Gus Dur attempted to see the state of society neglected by the government, criticized the relationship between the state and society, and the various capitalization phenomena that occurred. Indirectly, Gus Dur criticized mainstream Islamic theories, which in practice did not touch the problems of society.

Moeslim Abdurrahmman (1995) can also be equated as a reformer of Indonesian Islam who seeks to redefine Islam's prospects in Indonesia with his "Transformative Islam". Moeslim Abdurrahman is restless with models of symbolic piety, including a caricature social project for the mustad'afin. He wants an Islamic concept that is individual and has more social implications that can transformatively change a more humane social reality. Islam must not be a means of legitimating a group of rulers with economic and political resources. Islam must be able to display piety that takes sides against all processes of dehumanization. Masdar F. Mas'udi, a contemporary Islamic thinker in Indonesia, is also nervous about the textualist (scripturalist), ideological, and modernist model of Islam that does not provide liberation. Masdar mapped that based on his perspective, the development of Islamic discourse can be mapped as follows. First, scriptualistic, textualistic, and formalistic Islam, namely Islam whose focus or starting point and endpoint is text. Text functions as the tip and base or as the center. Islamic discourse starting from the book and ending to the text is al-awwal wa al-akhir. This scriptualist model lasted a very long time in the Islamic world. Because the discourse is so dominant, some even say that one of the three civilizations is a text civilization, namely a civilization ruled by Islam, as stated by Nasr Hamid Abu Zayd (Mas'udi, 2004, xi). Religion is an accumulation of texts (al-majmu'ah min al-nusūs) (Zayd, 1996, 9).

This scripture, textual, and formalistic Islam uses not only primary texts (al- 
Qur'an) but also secondary texts (hadiths) and tertiary texts (interpretation of both). All of these texts are sacred. Second, ideological Islam, which is Islam which departs not from worshiping the text but from the ideologization of its truth and ideas. The text becomes secondary, and the primary is the ideology. Text is used as justification, legitimacy, and justification. For this reason, ideological Islam becomes sectarian, closes itself off, and does not want to understand the others. The trigger for ideological Islam is usually a question of power, as seen in Islamic history's development with the emergence of Shia, Khawarij, and Sunni. Third, modernist Islam, namely a group carrying out the theological reconciliation of modern realities. In contrast to fundamentalist Islam which centers on ideological truth, modernist Islam centers on truths defined by others. Modernist Islam is an Islam that is making theological justifications and adjustments to the facts of modernity. Modernist Islam maintains that a Muslim cannot run away and can only make adjustments. The discourse is issue of modernity. Modernist Islam is a group that is currently dominant (Mas'udi, 2004, xv).

Based on the mapping of Islamic groups above, Masdar then took the term emancipatory to give identity to the liberation movement. According to him, basically, emancipatory Islam cannot be separated from the history of critical theory, so it is called essential Islam. Criticism has two elements. First, material reality, a thought that questions hegemonic ideology starting from real and material life or questions hegemony based on empirical reality. Second, a transformative vision that is committed to structural changes (relations), both power relations in the productive world (employer-laborers), as well as hegemonic ties in the relationship between the giver and recipient of the narrative (ulama-ummah), as well as political relations (rulers-people) (Mas'udi, 2004, Xv).

Meanwhile, Kuntowijoyo introduced the term prophetic social science to describe his liberating Islamic vision. Predictive social science or commonly abbreviated as ISP is one of Kuntowijoyo's important ideas. For him, social science should not become complacent in trying to explain or understand reality and then take it for granted. More than that, social science must also carry out the task of transformation towards society ideals idealized. Kuntowijoyo then formulated three basic values as the basis for prophetic social science based on QS. Ali 'Imran: 11o. Through this verse, Kuntowijoyo laid down three pillars for the Social Prophetic Science, namely humanization (ta'murūn bi alma'rūf), liberation (tanhawn' an almunkar), and transcendence (tu'minūn bi Allāh). These three pillars are then used as the basis for developing ISPs, and become their paradigmatic characteristics. The transcendence that must be based on the other two elements shows Kuntowijoyo's attention to the 
significance of religion in the theory building process in social science. Through transcendence, ISP wants to make religious values an essential part of the process of building civilization (Kuntowijoyo, 1998).

Harun Nasution, Gus Dur, Muslim Abdurrahman, Masdar F. Mas'udi, Kuntowijoyo thought were the answers in facing the changing times. The renewal movement shows the enthusiasm for critical and original thinking through the offer of a reconstruction of classical Islamic theology. The thoughts of reformers in Indonesia indicate a movement of Islamic thought in Indonesia that can be aligned with other Islamic thinkers in the world. Like Hassan Hanafi, who offers a reconstruction of Islamic theology from theocentric to theoanthropocentric, Indonesian Islamic reformers offer theology that no longer carries a theocentric theme but has entered a space that is genuinely cultural, anthropocentric theological, and sociological philosophical.

\section{Conclusion}

The explanation above shows that reconstructing classical Islamic theology is a necessity along with socio-cultural changes. Classical Islamic theology was born from the socio-political problems that surround it. Borrowing Hassan Hanafi's term, the birth of classical theology at that time was due to an attack based on the Islamic belief system, namely the transcendence of God carried out by representatives of old sects and cultures, and to fortify it; dialectics was built in order to defend oneself (as a concept) even though it is only a dialectic of words. Not a dialectic of ideas about history or the nature of society. In the modern age, Muslims are dealing with science and massive technological changes in the Western world. The backward Muslim community's condition in these changes was exacerbated by the emergence of various humanitarian problems such as oppression, backwardness, and injustice, both economically, socially, and politically. Therefore, classical Islamic theology, which is too theocentric-oriented, urgently needs to be reconstructed in a more humanoriented direction and has a practical value in human life.

Islamic reform that occurred in Indonesia also followed the process of Islamic reform in the world. One of the central issues in the renewal of Islamic thought that is the work of reformers is classical Islamic theology. Although using different terms, the built conceptions are the same, namely the need to carry out a reconstruction of classical Islamic theology. Like Ḥassan Hanafi, who introduced theo-anthropocentric theology, Harun Nasution introduced Rational Islam, Abdurrahman Wahid introduced the theology of transcendental humanism, Masdar F. Mas'udi offered emancipatory Islam, Moeslim Abdurrahman presented a transformative Islamic concept. Meanwhile, Kuntowijoyo taught the term social prophetic science to describe his liberating 
Islamic vision. The offer of reconstructing Islamic theology of reformers in Indonesia indicates a movement of Islamic thought in Indonesia that can be aligned with other Islamic thinkers in the Muslim world.

\section{References}

Abdurrahman, Moeslim, 1995, Islam Transformatif, Jakarta: Pustaka Firdaus.

Abdurrahman, Moeslim, 2005, Islam Yang Memihak, Yogyakarta: LKiS.

Amaladoss, Michael, 2001. Teologi Pembebasan Asia, terj. A. Widyamartaya dan Cindelaras, Yogyakarta: Insist

Andriansyah, Yuli, 2015, "Menggunakan Konsep 'At-Turāṡ Wa At-Tajdīd' dalam Pemikiran Ḥassan Ḥanafì untuk Mengatasi Kemiskinan Di Indonesia," Millah, 15 (1).

Andriansyah, Yuli, 2015. "Menggunakan Konsep al-Turas wa al-Tajdid", Jurnal Millah, 15 (1).

Anwar, M. Syafi'i, 1993, "Sosiologi Pembaharuan Pemikiran Islam Nurcholis Madjid" Jurnal Ulumul Qur'an, 1 (4).

Arif, Syaiful, 2013, Humanisme Gus Dur: Pergumulan Islam dan Kemanusiaan, Yogyakarta: Ar-Ruzz Media, 2013.

Azra, Azyumardi, 2003. "Menggugat Tradisi Lama, Menggapai Modernitas: Memahami Hassan Ḥanafi”, Kata Pengantar buku Ḥassan Hanafi, Dari Akidah ke Revolusi Sikap Kita Terhadap Tradisi Lama, terj. Asep Usman Ismail, et.al, Jakarta: Paramadina.

Barton, Greg, 1999, Gagasan Islam Liberal di Indonesia: Pemikiran Neo-Modernisme Nurcholish Madjid, Djohan Effendi, Ahmad Wahib, dan Abdurrahman Wahid, Jakarta: Paramadina.

Dahlan, Moh., 2013, Paradigma Ushul Fiqh Multikultural Gus Dur, Bengkulu: IAIN Bengkulu Press, 2013.

Fadal, Kurdi, 2014, "Tafsir Alquan Transformatif: Perspektif Hermeneutika Kritis Ḥassan Ḥanafi", Jurnal Penelitian,11, (2).

Faisol, M., 2011, "Menyikapi Tradisi: Membaca Proyek Pemikiran Kiri Islam" dalam Wasid, ed., Menafsirkan Trdaisi dan Modernitas: Ide-Ide Pembaharuan dalam Islam, (Surabaya: Pustaka Idea.

Farida, Umma, 2014, "Membincang Kembali Ahlussunnah Wa Al-Jamaah: Pemaknaan Dan Ajarannya Dalam Perspektif Mutakallimin," Fikrah 2, (1).

Hanafi, Hassan, 1981, Muqaddimah fi 'Ilm al-Istighrab, Kairo: Dar al-Faniyah.

Hanafi, Hassan, 1989. al-Din wa al-Thawrah fi Misr 1952-1981: al-Usuliyyah alIslamiyyah, Kairo: Maktabah Madbuli.

Hanafi, Hassan, 1991, Muqaddima fil 'Ilm al-Istighrab, Kairo: al-Dar al-Fanniyah.

Hanafi, Hassan, 2000, Islam In The Modern World: Religion, Ideology, And Development, Cairo: Dar Kebaa Bookshop. 
Hanafi, Hassan, 2000, Oksidentalisme: Sikap Kita Terhadap Tradisi Barat, terj. M. Najid Buchori, Jakarta: Paramadina.

Hanafi, Hassan, 2001, "Sebuah Pengantar", Aunul Abied Shah, ed., Islam Garda Depan: Mosaik Pemikiran Islam Timur Tengah, Bandung: Mizan.

Hanafi, Hassan, 2003, Aku Bagian dari Fundamentalisme Islam, terj. Kamran As'ad Irsyady dan Mufliha Wijayati, Yogyakarta: Islamika.

Hanafi, Hassan, 2003, Dari Akidah ke Revolusi Sikap Kita Terhadap Tradisi Lama, terj. Asep Usman Ismail dkk., Jakarta: Paramadina.

Hanafi, Hassan, 2003, Oposisi Pasca Tradisi, terj. Khairan Nahdiyyin, Yogyakarta: Syarikat Indonesia, Hanafi.

Hanafi, Hassan, tt., Membumikan tafsir Revolusioner, terj. Yudian Wahyudi \& Hamdiah Latif, Yogyakarta: Titian Ilahi Press, Hanafi.

Hanafi, Hassan, 1988. Min al-Aqidah ila al-Thawrah; Muhawalatun li I'adat bina' Usul al-Din, Kairo: Maktabah Madbuli.

Ḥassan Ḥanafi, 1989, al-Usuliyyah al-Islamiyyah, al-Din wa al-Thawrah fi Misr 1952-1981, Kairo: Maktabah Madbuli.

Iswahyudi, 2016, Pluralisme Islam Pribumi (Melacak Argumeen-argumen Abdurrahman Wahid tentang Pluralisme Islam di Indonesia), Ponorogo: STAIN Ponorogo Press.

Ja'far, Suhermanto, 2002, "Kiri Islam dan Ideologi Kaum Tertindas: Pembebasan Keterasingan Teologi Menurut Ḥassan Ḥanafı”, Jurnal al-Afkar, 5 (5).

Kuntowijoyo, 1998, Islam Sebagai Ilmu: Metodologi dan Etika (Jakarta: Penerbit Teraju, 2004) dan Paradigma Islam: Interpretasi Untuk Aksi, Bandung: Mizan, Kuntowijoyo.

Mas'udi, Masdar F., 2004, "Paradigma dan Metodologi Islam Emansipatoris" dalam Very Verdiansyah, Islam Emansipatoris: Menafsir Agama untuk Praksis Pembebasan, Jakarta: $\mathrm{P}_{3} \mathrm{M}$, Mas'udi.

Nitiprawira, Fr. Wahono, 200o, Teologi Pembebasan: Sejarah, Metode, Praksis, dan Isinya, Yogyakarta: LkiS.

Nurisman, 2005, Pemikiran Filsafat Islam Harun Nasution; Pengembangan Pemikiran Islam di Indonesia, Teras, Yogyakarta.

Prasetya, Marzuki Agung, 2013, "Model Penafsiran Ḥassan Hanafi", Jurnal Penelitian 7 (2).

Ridwan, AH., 1998. Reformasi Intelektual Islam, Yogyakarta: Ittaqa Press.

Shimogaki, Kazuo, 2012. Kiri Islam: Antara Modernisme dan Posmoderisme Telaah Kritis Pemikiran Hassan Hanafi, terj. M. Imam Aziz dan M. Jadul Maula, Yogyakarta: LKiS.

Soleh, A. Khudori, 2013, Filsafat Islam dari Klasik hingga Kontemporer, Yogyakarta: Ar-Ruzz.

Syafieh, 2020. "Pemikiran Teologi Teo-Antroposentris Ḥassan Ḥanafī" Disertasi, 
Fakultas Ushuluddin dan Studi Islam UIN Sumatera Utara.

Syaukani, Lutfi, 1994, "Oksidentalisme: Kajian Barat setelah Kritik Orientalisme”, Ulumul Qur'an, (5).

Verhak, C. and R, Haryono Verhak, 1997, Filsafat Ilmu Pengetahuan; Telaah Atas Cara Kerja Ilmu-Ilmu, Jakarta; Gramedia Pustaka Utama.

Wahid, Abdurrahman, 200o, Tuhan Tidak Perlu Dibela, Yogyakarta: LKiS.

Wahid, Abdurrahman, 2004, "Ḥassan Ḥanafì dan Eksperimentasinya", Kazuo Shimogaki, Kiri Islam: antara Modernitas dan Posmodernisme; Telaah Kritis Pemikiran Hassan Hanafi, terj. M. Imam Aziz dan M. Jadul Maula, (Yogyakarta: LkiS.

Wahid, Abdurrahman, 2006, Islamku, Islam Anda, Islam Kita: Agama Masyarakat Negara Demokrasi, Jakarta: The Wahid Institute.

Wahid, Marzuki, 200o, "Post-Tradisionalisme Islam: Gairah Baru Pemikiran Islam di Indonesia", Jurnal Tashwirul Afkar, (9).

Wahid, Marzuki, 2000, "Post-Tradisionalisme Islam: Gairah Baru Pemikiran Islam di Indonesia", Jurnal Tashwirul Afkar, (9). 